\title{
Florid osseous dysplasia, lesi radiopak bilateral pada radiograf panoramik
}

\author{
Ratih Trikusumadewi Lubis ${ }^{*}$, Fitri Angraini Nasution', Azhari $^{2}$, Farina Pramanik ${ }^{2}$
}

\begin{abstract}
Objectives: The aim of this report is to present a case of florid osseous dysplasia and understand its characteristics from panoramic radiography.

Case Report: A 47-years-old female patient came to the oral and maxillofacial radiology department at Dental and Oral Hospital of Universitas Padjadjaran to take panoramic radiography. Patient's chief complaints were pain on tooth 46 after being extracted about 4 days ago with numbness on the extraction area. Panoramic radiograph showed radioopaque lesions in the extraction area surrounded by a thin radiolucent area. In the periapical region of tooth 36 and 47 showed the

same radiopaque image as tooth 46 . The radiodiagnostic suspect of the lesions was bilateral florid osseous dysplasia in the posterior region of the mandible.

Conclusion: The images of florid osseous dysplasia from panoramic radiography are radioopaque, welldefined, sclerotic border, and having soft tissue capsule when the lesion is immature condition. The most common condition of FOD affect both upper and lower jaw, but if the lesion only occur in one jaw, the lesion commonly happen in mandible with exact location is more posterior than canine teeth.

${ }^{1}$ PPDGS Radiologi Kedokteran Gigi, Fakultas Kedokteran Gigi, Universitas Padjadjaran, Bandung, Indonesia, 40132

${ }^{2}$ Departemen Radiologi Kedokteran Gigi, Fakultas Kedokteran Gigi, Universitas Padjadjaran, Bandung, Indonesia, 40132

*Correspondence to:

Ratih Trikusumadewi Lubis

冈ratih08tl@gmail.com

Received on: October 2019 Revised on: December 2019 Accepted on: January 2020
Keywords: Fibro-osseous dysplasia, florid osseous dysplasia, osseous dysplasia, panoramic radiograph Cite this article: Lubis RT, Nasution FA, Azhari, Pramanik F. Florid osseous dysplasia, lesi radiopak bilateral pada radiograf panoramik. Jurnal Radiologi Dentomaksilofasial Indonesia 2019;3(3)39-42. https:// doi.org/10.32793/jrdi.v3i3.444

\section{PENDAHULUAN}

Istilah fibro-osseous lesion mengacu kepada perubahan metabolisme tulang normal yang berlangsung secara lokal dan menghasilkan pergantian dari seluruh komponen dari tulang cancelous oleh jaringan fibrous yang mengandung sejumlah besar gambaran tulang abnormal. ${ }^{1}$ Cemento-osseous dysplasia termasuk di dalam les jinak fibro-osseous. Istilah ini diganti dengan osseous-dysplasia (OD) oleh World Health Organization (WHO) pada tahun 2005, dan diklasifikasikan ke dalam bone dysplasia. OD terlokalisir pada daerah penyangga gigi atau pada tulang alveolar daerah tidak bergigi (edentulous) dan tidak berhubungan dengan penyakit skeleta lainnya. OD terdiri dari 4 tipe yaitu periapikal, fokal, florid dan familial gigantiform cementoma. ${ }^{2}$

Florid osseous dysplasia (FOD) merupakan suatu $O D$ yang dikemukakan pertama kali oleh Melrose pada tahun 1976 untuk menggambarkan penyebaran yang luas serta manifestasi penyakit yang luas di beberapa kuadran rahang, sebagian besar di rahang bawah dan bilateral simetris. ${ }^{3}$ Nama lain FOD disebut sebagai diffuse sclerosing osteomyelitis, sclerotic cemental masses, gigantiform cementoma dan multiple enostosis. ${ }^{4}$

FOD biasanya terjadi pada wanita kulit hitam usia dekade ke empat atau ke lima dengan rentang usia antara 19 hingga 76 tahun. $^{3}$ Selain itu juga sering terjadi pada ras Kaukasia dan Asia. Perbandingan wanita : pria $6: 1$ dan kecenderungan kulit hitam : kulit putih $6: 1 .{ }^{4}$ lesi ini asimptomatik dan sering ditemukan pada pemeriksaan radiografi rutin. Lesi dapat menjadi simptomatik karena infeksi sekunder, dan menjadi sulit untuk diobati setelah terinfeksi disebabkan oleh avaskularitas pada daerah FOD tersebut. ${ }^{1,6}$

Lesi ini lebih sering terjadi pada regio maksila, unilateral dan berbatas tidak jelas dengan gambaran internal berupa multiokular radiolusen

\section{LAPORAN KASUS}

Pasien perempuan berusia 47 tahun datang ke bagian radiologi Rumah Sakit Gigi dan Mulut Universitas Padjadjaran dengan rujukan untuk dilakukan pemeriksaan radiografis. Hasil anamnesa didapatkan adanya rasa sakit setelah pencabutan dengan penyulit gigi 46 sekitar 4 hari yang lalu disertai rasa kebas pada area bekas pencabutan. Pasien diberi antibiotik dan penghilang rasa sakit setelah pencabutan, tetapi sampai hari ke empat rasa sakit dan kebas tidak hilang. Dari hasil disertai radiopak. 
pemeriksaan intra oral terlihat bekas luka pencabutan gigi 46 masih terbuka.

Hasil radiograf panoramik (Gambar 1) menunjukkan lesi fibrous displasia. Lesi terlihat pada mandibula kuadran 3 dan 4, bilateral, tidak terdapat karies (gigi vital) ataupun resorpsi akar pada gigi 36, 46 dan 47. Lesi tidak mendorong akar gigi disebelahnya dan tidak mendorong canalis alveolaris inferior. Lesi juga tidak menyebabkan hilangnya tulang kortikal bukal dan lingual atau ekspansi ke arah bukal dan lingual. Akar terlihat seperti hipersementosis atau bersatu dengan tulang disekitarnya, sehingga bentuknya menjadi tidak jelas Lesi ini mempunyai batas yang ill-defined dengan campuran antara pola tulang trabekula yang normal dan abnormal pada regio post pencabutan gigi 46, periapikal 47 serta apikal 36 . Pada kasus lain, lesi ini juga dapat menunjukkan batas yang jelas dan tegas, terutama pada lesi yang masih baru.

Tingkat densitas dan pola trabecular pada lesi ini lebih bervariasi pada mandibula dibandingkan pada maksila. Gambaran tulang dapat berupa lebih radiolusen, lebih radiopak atau campuran antara keduanya dibandingkan gambaran tulang normal. Pada gambar 1, terlihat gambaran lesi multiopak, berbentuk granul, dengan batas jelas berupa radiolusen di sekeliling granul tersebut. Lesi kelilingi pita radiolusen (radiolucent band) tipis pada tulang alveolar dengan lesi berada di area apikal gigi molar mandibula kiri dan kanan. Kelainan bersifat lokal, multiple lesions, dan terletak diatas kanalis alveolaris inferior. Struktur internal lesi adalah radiopak ireguler pada gigi 36 dan radiopak ireguler pada apikal area bekas pencabutan gigi molar pertama kanan sampai molar kedua kanan, dengan batas jelas (well-defined border). Halo radiolusen tipis terlihat mengelilingi gambaran lesi radioopak gigi 36, 46, dan 47.

Berdasarkan radiograf panoramik tersebut dapat disimpulkan suspek radiodiagnosis lesi ini adalah florid osseous dysplasia (FOD) bilateral pada regio posterior mandibula.

\section{DISKUSI}

Kasus FOD yang dilaporkan ini terjadi pada area molar mandibula, hal ini sesuai dengan hasil penelitan yang dilakukan oleh Kunjir, Kumar dan Uppalwar (2016), dimana kasus FOD yang dilaporkan terjadi pada area gigi premolar dan molar mandibular dan mengenai dua kuadran (bilateral). ${ }^{7}$ Kasus serupa juga dilaporkan oleh Yildirim et al (2016), FOD terlihat dari radiograf panoramik dan Cone Beam Computed Tomography (CBCT) serta tidak terjadi ekspansi tulang kortikal bukal dan lingual. $^{8}$

Sedangkan Mahalingam dan Manoharan (2017) melaporkan kasus FOD multi kuadran pada gigi molar disertai hipersementosis beberapa akar gig dan hilangnya tulang kortikal bukal yang terlihat dari radiografi panoramik dan CBCT. ${ }^{9}$ Huh dan Shin (2013) melaporkan kasus FOD yang didiagnosis sebagai lesi inflamasi periapikal pada regio anterior mandibula, lesi terlihat multiple dengan struktur internal campuran radiolusen dan radiopak, menyebabkan hilangnya tulang kortikal labial dan lingual tanpa adanya ekspansi. ${ }^{10}$

Lesi FOD yang multiple (polyostotic) dapat ditemukan pada pasien anak berusia kurang dari 10 tahun, namun lesi yang monostotic sering ditemukan pada pasien yang berusia lebih tua. Lesi biasanya bersifat statis apabila pertumbuhan tulang sudah berhenti, namun proliferasinya dapat terus berlangsung terutama pada bentuk yang polyostotic. Lesi dapat aktif pada wanita hamil dan penggunaan obat kontrasepsi, pertumbuhan abnormal dapat terjadi apabila ada interfensi bedah pada pasien yang masih muda.

Penelitian menunjukkan bahwa distribusi lesi FOD tidak tergantung terhadap jenis kelamin

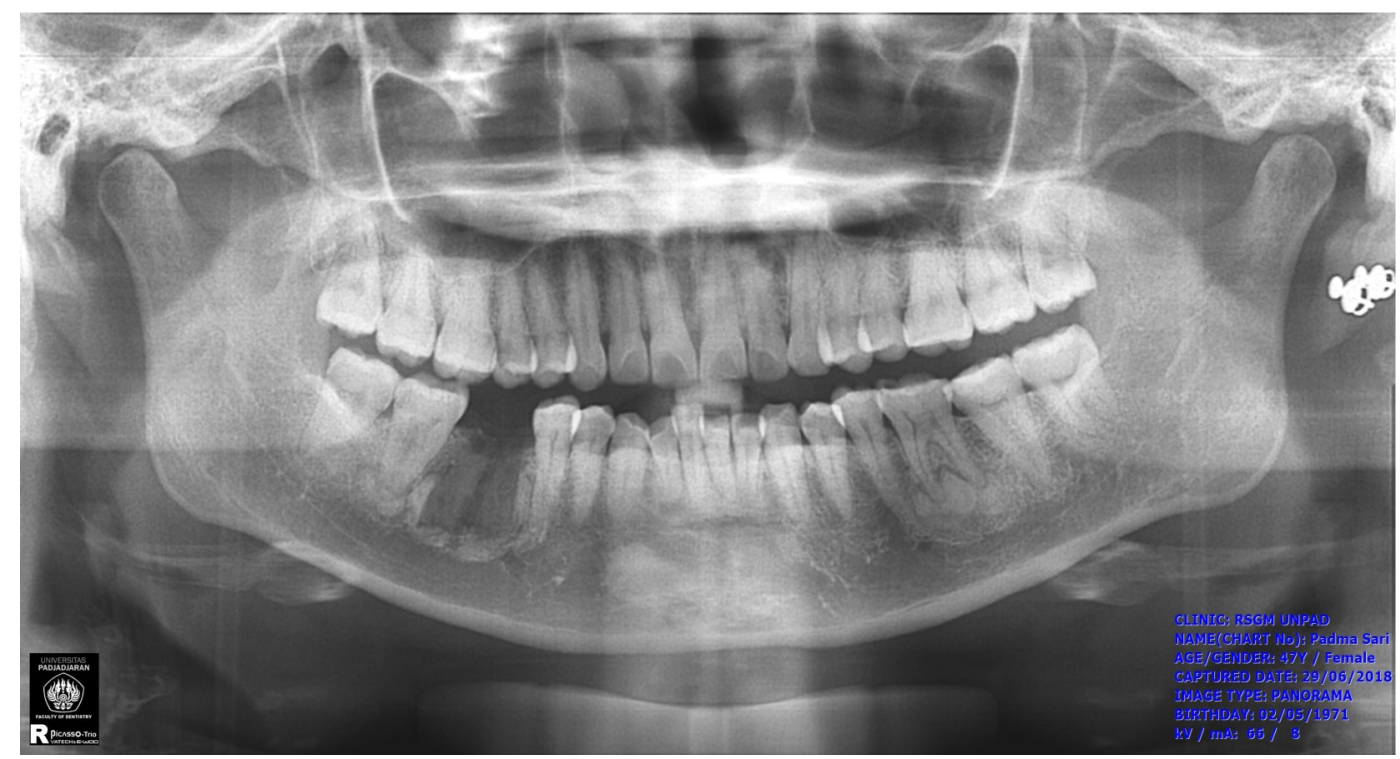

Gambar 1. Radiograf panoramik memperlihatkan lesi radiopak pada area bekas pencabutan gigi 46 sampai dengan periapikal gigi 47 , lesi yang sama terlihat pada periapikal gigi 36 
kecuali pada McCune-Albright syndrome yang lebih banyak terjadi pada wanita.

Diagnosa banding florid osseous dysplasia adalah Paget's disease, periapikal cementodysplasia dan chronic sclerosing osteomyelitis. Paget's disease lebih sering terjadi pada usia pasien yang lebih tua, dan terjadi pada seluruh bagian mandibula, dibandingkan dengan lesi FOD yang hanya bersifat unilateral atau bilateral pada mandibula regio posterior. Secara umum periapikal cemento-dysplasia mempunyai gambaran pola tulang yang serupa namun memiliki pola distribusi yang berbeda dimana sering terjadi secara bilateral dengan regio periapikal sebagai epicenter, periapikal cemento-dysplasia juga sering terjadi pada usia yang lebih tua.

Pada lesi osteomyelitis, sering terdapat pembesaran dari tulang rahang, namun pembesaran tersebut berasal dari periosteum, dimana tulang yang baru berada pada lapisan luar korteks, dan pemeriksaan lebih detail menunjukkan bahwa masih terdapat bagian korteks yang awal dalam bagian rahang yang meluas. hal ini berbeda dari FOD, dimana lesi berupa perluasan dari aspek internal dari tulang, terdapat pergeseran dan penipisan pada lapisan luar korteks sehingga korteks yang tersisa mempertahankan posisinya pada bagian luar tulang.

\section{SIMPULAN}

Radiograf panoramik dapat digunakan untuk menganalisa lesi florid osseous dysplasia. Biasanya Florid osseous dysplasia tidak memiliki gejala dan ditemukan pada pemeriksaan radiografi secara tidak disengaja, kadang pasien mengeluh nyeri dengan intermiten derajat rendah, dan terlokalisasi dengan baik pada tulang yang terkena terutama ketika kista tulang yang sederhana telah berkembang di lesi tersebut. Gambaran radiologi florid osseous dysplasia umumnya campuran radiolusen dan radiopak dikelilingi halo radiolusen dengan batas jelas (well-defined, sclerotic border). Lesi florid osseous dysplasia yang besar dapat menyebabkan gangguan pada struktur disekitarnya seperti impaksi dan perubahan tempat gigi didekatnya dan ditandai dengan perluasan tulang kortikal. CBCT (Cone Beam Computed Tomography) merupakan alternatif teknik pilihan yang dapat dipertimbangkan dalam menentukan batas lesi florid osseous dysplasia, ekspansi, tulang kortikal yang menipis dan perforasi.

\section{DAFTAR PUSTAKA}

1. White SC, Pharoah MJ. Oral Radiology Principles and Interpretation. 7th ed. St Louis: Elsevier; 2014

2. Barnes L, Eveson JW, Reichart P, Sidransky D (eds.). Pathology and Genetics of Head and Neck Tumours. Lyon: IARC Press; 2005:284

3. Melrose RJ, Abrams AM, Mills BG. Florid Osseous Dysplasia. A clinical-pathologic study of thirty-four cases. Oral Surg Oral Med Oral Pathol 1976;41:62-82

4. Peter AR, Phillipsen HA. Odontogenic Tumors and Allied Lesions. 1st ed. London: Quintessence; 2004

5. Oikarinen K, Altonen M, Happonen RP. Gigantiform Cementoma Affecting a Caucasian Family. Br J Oral Maxillofac Surg. 1991;29:194-197

6. Lin TM, Huang WH, Chiang CP, Lin HN, Liao YS, Chiang ML. Florid Cemento-Osseous Dysplasia (FCOD): Case Report. J Dent Sci 2010;5:242-5

7. Kunjir G, Kumar RK, Uppalwar P. Florid Cemento-Osseous dysplasia. IJSS Case Reports and Reviews. 2016 March;2

8. Yildirim E, Baglar S, Ciftci ME, Ozcan E. Florid CementoOsseous Dysplasia : A Rare Case Report Evaluated With Cone Beam Computed Tomography. J Oral Maxillofac Pathol. 2016 May-Aug;20(2): 329

9. Mahalingam G, Manoharan GV. Florid Osseous Dysplasia Report of Two Cases and Review of Literature. J Clin Diagn Res 2017 Jan;11(1):ZD21-ZD24

10. Huh JK, Shin SJ. Missdiagnosis of Florid Cemento-Osseous Dysplasia Leading to Unnecessary Root Canal Treatment : A Case Report. Restor Dent Endod. 2013 Aug;38(3):160-166 